\title{
Importance of Detection of Isoniazid and Rifampicin Mono Drug Resistance and Determining Rate of MDR-TB in Smear Positive Sputum Samples from a Tertiary Care Hospital of West U.P. India
}

\author{
Sana Nudrat ${ }^{1}$, Umar Farooq ${ }^{1 *}$ and Mazhar Maqsood ${ }^{2}$ \\ ${ }^{1}$ Department of Microbiology, Teerthankar Mahaveer Medical College, Moradabad - 244 001, India. ${ }^{2}$ Department \\ of Pulmonary Medicine, Teerthankar Mahaveer Medical College, Moradabad - 244 001, India.
}

\begin{abstract}
Anti-tubercular therapy is one of the effective strategies used to control tuberculosis, so, a planned and accurate treatment regimen is of utmost importance, but number of cases are being treated as MDR on the basis of rifampicin mono resistance. As reported earlier in various studies from India, prevalence rate of Multi Drug Resistant-Tuberculosis (MDR-TB) vary from region to region. Therefore, we set out to determine rate of MDR-TB, Isoniazid and Rifampicin Mono resistance and common mutation pattern associated with them from our area using GenoType MTBDR plus assay in order to provide better patient care and reduce rate of MDR-TB. This was a Cross-sectional study comprising of 1100 sputum samples collected from DOTS Centre and processed by ZN staining and LPA. Out of 1100 sputum samples, 203 were smear positive. In 203, 193 were detected as positive for MTBC. Rate of MDR was found 12.8\% and rifampicin and isoniazid mono-resistance was $6.4 \%$ and $8.3 \%$ respectively. Commonest mutation pattern seen was S531L in rifampicin and S315T1 in isoniazid. Association between treatment history and resistance pattern was found to be statistically significant. We found there is a high rate of INH mono resistance which was not being detected till now from this area and we also found, there is unrelated risk of isoniazid and rifampicin mono-resistance so, inference of MDR based on RIF mono- resistance is also an inaccurate strategy to manage patients and drug sensitivity should be performed for both first line drug before stating MDR.
\end{abstract}

Keywords: InhA, katG, Line probe assay, Polymerase chain reaction, rpoB.

\footnotetext{
*Correspondence: nudratsana1@gmail.com

(Received: 22 March 2019; accepted: 20 May 2019)

Citation: Sana Nudrat, Umar Farooq and Mazhar Maqsood, Importance of Detection of Isoniazid and Rifampicin Mono Drug Resistance and Determining Rate of MDR-TB in Smear Positive Sputum Samples from a Tertiary Care Hospital of West U.P. India, J Pure Appl Microbiol., 2019; 13(2): 1079-1085. doi: 10.22207/JPAM.13.2.46

(c) The Author(s) 2019. Open Access. This article is distributed under the terms of the Creative Commons Attribution 4.0 International License which permits unrestricted use, sharing, distribution, and reproduction in any medium, provided you give appropriate credit to the original author(s) and the source, provide a link to the Creative Commons license, and indicate if changes were made.
} 


\section{INTRODUCTION}

Tuberculosis remains as one of the most common infectious disease in developing countries still in $21^{\text {st }}$ century ${ }^{1}$. Tuberculosis is an important international health problem and this issue has become even more prominent as a result of increasing number of drug resistant strains ${ }^{2}$. Anti-tubercular therapy is one of the effective strategies used to control tuberculosis. First line drugs including rifampicin, isoniazid, ethambutol, pyrazinamide and streptomycin are the preferred choice for TB control. Recently MDR - TB strains has become a serious public health problem in developing countries and has consistently been contributing to increased annual TB incidence rates $^{3}$. Resistant to at least isoniazid and rifampicin is of great concern because it requires the use of second line drugs that are difficult to procure and are much more toxic and expensive than the first line regime. Based on a survey, among all $M$. tuberculosis isolates tested for drug susceptibility, $10.9 \%$ were resistant to one anti TB drug and $6.7 \%$ were resistant to both isoniazid and rifampicin. It has been proved that patients infected with strains resistant to rifampicin will experience a higher failure rate with short course 6 months chemotherapy. Globally an estimated $3.6 \%$ of new cases and $20.2 \%$ of previously treated cases are due to MDR $-\mathrm{TB}^{4}$.

Rifampicin is an effective drug against Mycobacterium tuberculosis complex, which interferes with transcription by the DNA dependent RNA polymerase. In most cases resistance to rifampicin is linked with mutation within $81 \mathrm{bp}$ hypervariable or hot spot region of rifampicin resistance determining region (RRDR) of the $r p o B$ gene. Detection of $r p o B$ gene mutation is considered a surrogative marker for MDR - TB detection and can be used as a tool in MDR - TB diagnostics. In Isoniazid, resistance is associated with mutation in inhA (position -15 and -8 in the inhA promoter sequence), KatG (codon 315$)^{5}$.

Mutation in the $81 \mathrm{bp} \mathrm{RRDR}$ of the $r p o B$ gene are found in about $96 \%$ of rifampicin resistant in M. tuberculosis. Mutation at codon 516, 526 and 531 are among the most frequently mutation in rifampicin resistant strains. For isoniazid resistant clinical isolates mutation within the katG gene occur most frequently between codon 138 and 328 , particularly at codon 315 , accounting for 50 -
95\%. Mutation at position -15 and -8 in the inhA regulatory region is $6-43 \%{ }^{6}$.

The World Health Organization (WHO) recommended a new policy to use Line Probe Assay (LPA) for rapid screening of patients at risk of MDR - TB in 2008. Geno Type MTBDRplus assay (Hain Life Sciences) targets the rpoB gene (coding for beta subunit of RNA polymerase), katG coding for Catalase peroxidise) and promoter region of inhA (coding for NADH enoyl ACP reductase) gene in both culture isolates and clinical samples. Addition to rifampicin resistance ( $r p o B$ gene), MTBDRplus assay aids in the detection of high level and low level resistance to isoniazid via katG gene and inhA gene respectively ${ }^{7,8}$.

As reported in various studies from India, prevalence rate of MDR-TB vary from region to region. Therefore, we set out to determine rate of MDR-TB, mono drug resistance and common mutation pattern from our area using GenoType MTBDRplus assay.

\section{MATERIALS AND METHODS Study design and setting}

This was a laboratory based cross sectional study which was carried out in molecular section of Microbiology Department, Teerthankar Mahaveer Medical College and Research Centre, Moradabad, Uttar Pradesh, India.

\section{Specimen Collection}

1100 sputum samples were collected from the patients in a clean sterile universal containers attending DOTS centre of Teerthankar Mahaveer Hospital. These samples were transported to Microbiology laboratory according to international standards of WHO recommendation for transport of biological substances.

\section{Sputum Microscopy}

These samples were processed for smear microscopy by Z-N staining. 203 samples were smear positive.

\section{Decontamination}

Smear positive sputum specimens were processed for decontamination by mixing $\mathrm{N}$-acetyl$\mathrm{L}$-cysteine and $\mathrm{NaOH}$ in the specimen and incubate for $15 \mathrm{~min}$. After that, phosphate buffer was added to the specimen and centrifugation was done for $15 \mathrm{~min}$ at $3000 \mathrm{~g}$. Then, discard the supernatant and re-suspend the pellet in $1 \mathrm{ml}$ phosphate buffer. $^{9}$ 


\section{DNA extraction}

$500 \mu \mathrm{l}$ of the decontaminated specimen was processed in the micro centrifuge (13000rpm for $15 \mathrm{~min}$ at room temp.) The supernatant was discarded and the pellet was re-suspended in $100 \mu \mathrm{l}$ of distilled water and then inactivates the bacteria by incubating in a heating block for 20 minutes at $95^{\circ} \mathrm{C}$. After that cells were sonicated in an ultrasonic bath for 15 minutes and centrifuge for 5 minutes at $13000 \mathrm{rpm}^{9}$

\section{DNA Amplification}

Amplification was performed by combining $35 \mu$ l of primer nucleotide mix (PNM A) containing buffer, nucleotides, Taq polymerase and $10 \mu$ l of primer nucleotide mix (PNM B) containg salt, specific primers, dye. $5 \mu$ l extracted DNA was mixed in the master mixture (A and $B$ ). After that, this mixture was kept in the Thermocycler for the amplification of the bacterial DNA.

\section{Amplification Cycle}

$$
\begin{array}{lll}
15 \mathrm{~min} & 95^{\circ} \mathrm{C} & 1 \text { cycle } \\
30 \mathrm{sec} & 95^{\circ} \mathrm{C} & \\
2 \mathrm{~min} & 65^{\circ} \mathrm{C} & 20 \text { cycles } \\
25 \mathrm{sec} & 95^{\circ} \mathrm{C} & \\
40 \mathrm{sec} & 50^{\circ} \mathrm{C} & \\
40 \mathrm{sec} & 70^{\circ} \mathrm{C} & 30 \text { cycles } \\
8 \mathrm{~min} & 70^{\circ} \mathrm{C} & 1 \text { cycle }
\end{array}
$$

\section{Genotype MTBDRplus (ver 2.0)}

Hybridization was performed manually using Twin incubater / shaking water bath at $45^{\circ} \mathrm{C}$ as per manufacturer's instructions. ${ }^{8}$

\section{Observation and Results}

During the study period July 2015 to June 2017 , out of 1100 sputum samples processed for Z-N staining, 203(18.4\%). samples were positive for AFB. M. tuberculosis complex MTBC was positive in 193 cases out of 203 and 10 samples (4.9\%) were detected as Non Tuberculous Mycobacterium (NTM). All 193 M. tuberculosis isolates were

Table 1. Distribution of drug sensitivity pattern in patients

\begin{tabular}{ll}
\hline $\begin{array}{l}\text { Drug Sensitivity } \\
\text { pattern }\end{array}$ & $\begin{array}{l}\text { Number of } \\
\text { Samples }\end{array}$ \\
\hline MDR & $26(12.8 \%)$ \\
Rifampicin mono-resistant & $13(6.4 \%)$ \\
Isoniazid mono-resistant & $17(8.3 \%)$ \\
Sensitive to both drugs & $137(67.4 \%)$ \\
NTM & $10(4.9 \%)$
\end{tabular}

processed for drug sensitivity by PCR and Line Probe Assay. Out of 193, 26 (12.8\%) were MDR, $13(6.4 \%)$ were rifampicin mono-resistant, 17 (8.3\%) were isoniazid mono-resistant and 137 (67.4\%) were sensitive to both drugs rifampicin and isoniazid as shown in Table 1.

In this study, all smear positive cases are divided in 2 categories. 59 cases were in category 1 and 134 were in category 2 . Patients in category 1 had not taken anti-tubular drugs previously, i.e; they all were new cases. In category 2 all 134 patients had previously received anti-tubular drugs. Category 2 patients were further classified as defaulter i.e., those who left treatment in between the course of DOTS therapy. Failure cases who remained smear positive after 2 months of treatment and relapse cases were those who turned smear positive again after successful full term DOTS therapy, as shown in Table 2.

In our study a higher prevalence rate of MDR, rifampicin and isoniazid mono-resistance was found among males i.e. 9.3\%, $4.4 \%$ and $5.9 \%$ respectively, and majority of patients were in age group of 26-35 years followed by 36-45 and 46-55 years age group, but neither age nor sex was significantly associated with MDR or mono-

Table 2. Category wise distribution

\begin{tabular}{lccc}
\hline \multirow{2}{*}{ Category } & \multicolumn{3}{c}{ No. of patientsTotal no } \\
\cline { 2 - 4 } & Male & Female & patients \\
\hline 1 & $44(21.6 \%)$ & $15(7.3 \%)$ & $59(29.0 \%)$ \\
2 & $96(47.2 \%)$ & $38(18.7 \%)$ & $134(66.0 \%)$ \\
& 140 & 53 & 193 \\
\hline
\end{tabular}

resistant status. ( $p$ value $>0.05$ ) as shown in Table 3 and Table 4.

We also found a higher rate of MDR, RIF and INH mono-resistance among defaulter category, $53.8 \%, 46.1 \%$ and $47.0 \%$ respectively and sensitivity to both first line drugs was seen highest in new patient category (39.4\%). p value calculated was $<.05$ which shows there is significant association between treatment history of patient and drug resistance, also by calculating OR it was found that there are 7.03 times more chances of MDR-TB in defaulter cases as compared to new cases, so it is a significant risk factor as shown in Table 5. 
Table 3. Sex wise distribution pattern among different drug resistant cases

\begin{tabular}{|c|c|c|c|c|c|c|c|c|}
\hline & MDR & $\begin{array}{l}\chi^{2}, \mathrm{df} \\
P \text { value }\end{array}$ & $\begin{array}{l}\text { RIF mono } \\
\text { resistant }\end{array}$ & $\begin{array}{l}\chi^{2}, \mathrm{df} \\
\mathrm{P} \text { value }\end{array}$ & $\begin{array}{l}\text { INH mono } \\
\text { resistant }\end{array}$ & $\begin{array}{l}\chi^{2}, \mathrm{df} \\
\mathrm{P} \text { value }\end{array}$ & $\begin{array}{l}\text { Sensitive to } \\
\text { both drugs }\end{array}$ & $\begin{array}{l}\chi^{2}, \mathrm{df}, \\
\mathrm{P} \text { value }\end{array}$ \\
\hline Male & $19(9.3 \%)$ & $\begin{array}{l}0.01,1 \\
0.89\end{array}$ & $09(4.4 \%)$ & $\begin{array}{l}0.05,1, \\
0.81\end{array}$ & $12(5.9 \%)$ & $\begin{array}{l}0.01,1, \\
0.89\end{array}$ & $99(48.7 \%)$ & $\begin{array}{l}0.01,1, \\
0.906\end{array}$ \\
\hline Female & $07(3.4 \%)$ & & $04(1.9 \%)$ & & $05(2.4 \%)$ & & $38(18.7 \%)$ & \\
\hline Total & 26 & & 13 & & 17 & & 137 & \\
\hline
\end{tabular}

Frequency of gene mutation associated with resistance to rifampicin $(r p o B)$ and isoniazid (katG or inhA) are shown in Table 6 . Out of 26 MDR cases, for rpoB gene WT 2 band is absent in 3 cases at 510-513 gene region and mutation L511P is present. In 6 cases WT 3,4 band is absent at 513519 gene region and D516V mutation is present. 16 cases, WT 8 band is absent at $530-533$ gene region and in 12 cases MUT3 band is present with S531L mutation. In 2 cases MUT2B band is present at 526529 gene region and mutation H526D is present.
In $k a t G$ gene WT band is absent in 14 cases at 315 gene region and MUT1 band is present in 18 cases at with S315T1 mutation. In inhA gene WT1 band is absent in 6 case at -15/-16 gene region and MUT1 band is present in 3 cases at -15 gene region and C15T mutation is present. In only 1 case WT2 band is absent at -8 gene region.

In 13 RIF monoresistance cases, in 1 case WT2 band is absent at $510-513$ gene region and L511P mutation is present. In 1 case WT4, 5 band is absent at $516-522$ gene region and mutation

Table 4. Age wise distribution of patients

\begin{tabular}{lcccccc}
\hline $\begin{array}{l}\text { Age } \\
\text { Group }\end{array}$ & $\begin{array}{c}\text { MDR } \\
(\%)\end{array}$ & $\begin{array}{c}\text { RIF } \\
\text { Mono- } \\
\text { resistant }\end{array}$ & $\begin{array}{c}\text { INH } \\
\text { Mono- } \\
\text { resistant }\end{array}$ & $\begin{array}{c}\text { Sensitive } \\
\text { to Both } \\
\text { Drugs }\end{array}$ & $\begin{array}{c}\text { No.of Pt in } \\
\text { particular } \\
\text { age group }\end{array}$ & $\begin{array}{c}\chi^{2} \mathrm{df}, \\
\text { P value }\end{array}$ \\
\hline $15-25$ & 01 & 01 & 01 & 17 & 20 & 6.646, \\
$26-35$ & 06 & 02 & 05 & 34 & 47 & $15,0.96$ \\
$36-45$ & 08 & 03 & 03 & 25 & 39 & \\
$46-55$ & 05 & 03 & 03 & 19 & 30 & \\
$56-65$ & 03 & 01 & 02 & 19 & 25 & \\
66 and & 03 & 03 & 03 & 23 & 32 & \\
above & & 13 & 17 & 137 & 193 & \\
Total & 26 & 13 & & & & \\
\hline
\end{tabular}

Table 5. Rifampicin and Isoniazid resistance pattern in relation to tuberculosis treatment history

\begin{tabular}{|c|c|c|c|c|c|c|}
\hline $\begin{array}{l}\text { Drug } \\
\text { resistant } \\
\text { pattern }\end{array}$ & Category & MDR & $\begin{array}{l}\text { RIF } \\
\text { mono } \\
\text { resistant }\end{array}$ & $\begin{array}{l}\text { INH } \\
\text { mono } \\
\text { resistant }\end{array}$ & $\begin{array}{l}\text { Sensitive } \\
\text { to both } \\
\text { drugs }\end{array}$ & $\begin{array}{l}\chi^{2}, \mathrm{df}, \\
p \text { value }\end{array}$ \\
\hline $\begin{array}{l}\text { New } \\
(n=59)\end{array}$ & 1 & $\begin{array}{l}02 \\
(7.6 \%)\end{array}$ & $\begin{array}{l}02 \\
(15.3 \%)\end{array}$ & $\begin{array}{l}01 \\
(5.8 \%)\end{array}$ & $\begin{array}{l}54 \\
(39.4 \%)\end{array}$ & \\
\hline $\begin{array}{l}\text { Failure } \\
(n=25)\end{array}$ & 2 & $\begin{array}{l}03 \\
(11.5 \%)\end{array}$ & $\begin{array}{l}03 \\
(23.0 \%)\end{array}$ & $\begin{array}{l}05 \\
(29.4 \%)\end{array}$ & $\begin{array}{l}14 \\
(10.2 \%)\end{array}$ & $\begin{array}{l}22.567,9 \\
0.0072\end{array}$ \\
\hline $\begin{array}{l}\text { Relapse } \\
(n=38)\end{array}$ & & $\begin{array}{l}07 \\
(26.9 \%)\end{array}$ & $\begin{array}{l}02 \\
(15.3 \%)\end{array}$ & $\begin{array}{l}03 \\
(17.6 \%)\end{array}$ & $\begin{array}{l}26 \\
(18.9 \%)\end{array}$ & \\
\hline $\begin{array}{l}\text { Defaulter } \\
(n=71)\end{array}$ & & $\begin{array}{l}14 \\
(53.8 \%)\end{array}$ & $\begin{array}{l}06 \\
(46.1 \%)\end{array}$ & $\begin{array}{l}08 \\
(47.0 \%)\end{array}$ & $\begin{array}{l}43 \\
(31.3 \%)\end{array}$ & \\
\hline $\begin{array}{l}\text { Total } \\
(n=193)\end{array}$ & & 26 & 13 & 17 & 137 & $p<.05$ \\
\hline
\end{tabular}


Table 6. Frequency of gene mutation associated with resistance to rifampicin ( $r p o B)$ and isoniazid (katG or inhA)

\begin{tabular}{|c|c|c|c|c|c|c|}
\hline \multicolumn{2}{|l|}{ Gene } & \multirow{2}{*}{$\begin{array}{l}\text { Band } \\
\text { WT } 1\end{array}$} & \multirow{2}{*}{$\begin{array}{l}\begin{array}{l}\text { Gene region / } \\
\text { Mutation }\end{array} \\
506-509\end{array}$} & \multirow[t]{2}{*}{ MDR } & \multirow[t]{2}{*}{$\begin{array}{l}\text { RIF } \\
\text { resistance }\end{array}$} & \multirow[t]{2}{*}{$\begin{array}{l}\text { INH } \\
\text { resistance }\end{array}$} \\
\hline$r p o B$ & 1 & & & & & \\
\hline & 2 & WT 2 & $510-513$ & 03 & 01 & \\
\hline & 3 & WT 3,4 & $513-519$ & 06 & & \\
\hline & 4 & WT 4,5 & $516-522$ & & 01 & \\
\hline & 5 & WT 5,6 & $518-525$ & & & \\
\hline & 6 & WT 7 & $526-529$ & & & \\
\hline & 7 & WT 8 & $530-533$ & 16 & 09 & \\
\hline & 8 & MUT 1 & D516V & & & \\
\hline & 9 & MUT 2A & H526Y & & 01 & \\
\hline & 10 & MUT 2B & H526D & 02 & 02 & \\
\hline & 11 & MUT 3 & S531L & 12 & 03 & \\
\hline \multirow[t]{3}{*}{ katG } & 12 & WT & 315 & 14 & & 09 \\
\hline & 13 & MUT1 & S315T1 & 18 & & 14 \\
\hline & 14 & MUT2 & S315T2 & & & \\
\hline \multirow[t]{6}{*}{$\operatorname{inh} A$} & 15 & WT1 & $-15 /-16$ & 06 & & 02 \\
\hline & 16 & WT2 & -8 & 01 & & 02 \\
\hline & 17 & MUT1 & $\mathrm{C} 15 \mathrm{~T}$ & 03 & & 01 \\
\hline & 18 & MUT2 & A16G & & & \\
\hline & 19 & MUT3A & $\mathrm{T} 8 \mathrm{C}$ & & & \\
\hline & 20 & MUT3B & T8A & & & \\
\hline
\end{tabular}

N518L is present. In 9 cases WT8 band is absent at 530-533 gene region and MUT3 band is present in 3 cases with S531L mutation. In 1 and 2 case, MUT2A and MUT2B band is present at 526-529 gene region and mutation $\mathrm{H} 526 \mathrm{Y}$ and $\mathrm{H} 524 \mathrm{D}$ is present.

In 17 INH monoresistance cases, for katG gene, WT band is absent in 9 cases at 315 gene region and MUT1 band is present in 14 cases with mutation S315T1. In inhA gene, WT1 band is absent at -15/-16 gene region and MUT1 band is present in 1 case with C15T mutation. In 1 case WT2 band is absent at -8 gene region.

\section{Statistical Analysis}

The collected data was entered in Microsoft excel and analysed using SPSS version 21 (SPSS Inc, Chicago, IL, USA) software was used for making proportional and analysing table. Chi square test was used to determine the association between different variables. $\mathrm{P}$ value $<0.05$ was considered statistically significant.

\section{DISCUSSION}

In this study, it was observed that the rate of TB infection was found to be more in male and the male to female ratio of $2.6: 1$.
Similarly, high male to female ratio was reported by Singhal et $a f^{9}$ and $\mathrm{RaO}^{10}$. Although association was found statistically insignificant and could be because males are exposed more to risk factors as compared to females, Age wise distribution of patients also reviled fruitful observations which showed out of 203 more than $50 \%$ of patients belong to 26-55 years age group similar findings were reported by $\mathrm{RaO}^{10} \mathrm{WHO}$ also reports that TB mostly affects adults in their most productive years. ${ }^{11}$ These observations may have strong implication in TB control strategies.

In present study, MDR TB rate found is $12.8 \%$ which is comparatively higher to previously reported by some authors from India like $4.7 \%$ reported by Gupta et al, ${ }^{12}$ from Lucknow in 2013; $4.5 \%$ reported by Malhotra et al. ${ }^{13}$ from Jaipur in 2002 whereas it is quite low when compared few other studies, such as $14.6 \%$ reported by Thakur et $a l,{ }^{14}$ from Solan H.P. in 2015; $21.0 \%$ reported by Ahmad et al. ${ }^{15}$ from Aligarh in 2017 which indicates rate of MDR-TB vary from region to region. In this study moderate rate of MDR TB was observed as only smear positive patients were included in this study whereas studies which reported lower rates included all smear positive and negative cases 
and studies which reported higher rates included exclusively MDR-TB suspected cases.

Simultaneously, rate of RIF and INH mono-resistance found in this study was $6.4 \%$ and $8.3 \%$ respectively, while other studies from India reported RIF mono-resistance rate of $5.8 \%, 19.4 \%$, $5.4 \%, 8.8 \%$ from Aligarh ${ }^{15}$, Solan ${ }^{14}$, Varanasi $^{16}$, and Delhi ${ }^{17}$ respectively and INH mono resistance from same studies were reported as $9.2 \%, 20.35,6.3 \%$, and $8.5 \%$. TB control programmes generally focus on MDR-TB because these strains are difficult to treat and cause much morbidity and mortality. Many drug resistant surveys have shown that mono and poly resistant TB are actually more common than MDR TB ${ }^{14-17}$. we also found that rate of mono resistance was more as compared to rate of MDR TB ( $14.7 \%$ and $12.8 \%$ respectively). Many of these cases contribute towards amplification of resistance and eventually lead to MDR if they are not properly managed.

In this study it was also observed that prevalence rate of MDR TB is quite high in defaulter, relapse and failure cases as compared to new cases. Prevalence rate for defaulter cases of MDR was $53.8 \%$, for relapse cases it was $26.9 \%$ and $11.5 \%$ for failure cases which is quite high as compared to prevalence rate of MDR in new cases which was $7.6 \%$. These findings support previously reported findings of Thakur et al. ${ }^{14}$ Malhotra et al. ${ }^{13}$ Ahmad et al. ${ }^{15}$ and Talesse et al. ${ }^{18}$ statistically a significant association was found between treatment history and drug resistance $(p<0.05)$ so it can be said treatment failure or defaulter is significantly associated with drug resistance in TB cases.

Thakur C et al. ${ }^{14}$ in 2015 reported most common mutation is associated with rpoB 530533 region mostly S531L mutation (62.2\%). We also found S531L mutation as the most common mutation associated with rifampicin resistance (61.5\%). This resistance was also most common in both MDR cases and rifampicin mono-resistance cases. Similar finding were reported by Hirani et al. ${ }^{19}$ and Sharma et al. ${ }^{20}$ Most common mutation associated with isoniazid mono-resistance was S315T1 at region 315. Similar findings were reported by Swaminathan et $a .^{21}$ and Meaza et al. ${ }^{22}$

\section{CONCLUSION}

The author found that there is high rate of INH mono resistance which was unrelated to rifampicin mono-resistance so, inference of MDR based on RIF mono- resistance may be an inaccurate strategy to manage patients. Many of the Mono resistant cases contribute towards amplification of resistance and eventually lead to MDR if they are not managed properly, these cases often remain undiagnosed in resource limited settings and also DST is recommended only for that group of patients those are at high risk of developing MDR. Correct treatment of mono drug resistant TB can prevent development of MDRTB. All TB patients infected with rifampicin mono resistant strains should be treated using a full MDR TB regimen with isoniazid being added in the regimen until DST results to isoniazid are available. If DST of isoniazid shows susceptibility it can be continued in the MDR-TB regimen. Whereas, patients infected with isoniazid mono resistant strains can be treated with rifampicin along with ethambutol and pyrazinamide with caution and with monitoring for possible rifampicin amplification. Performing rapid DST to isoniazid and rifampicin with LPA at the start of treatment would help identify many more cases of mono drug resistance and thus providing appropriate treatment and controlling spread of MDR-TB.

\section{ACKNOWLEDGEMENTS}

Authors are grateful to Dr. Umme Afifa for help in statistical analysis. SN also acknowledges support of Shivendra Mohan for help in sample processing and data collection.

\section{CONFLICT OF INTEREST}

The Authors declare that there is no conflict of interest.

\section{AUTHOR'S CONTRIBUTION}

SN performed the tests, collected data, done data analysis and wrote the manuscript. UF guided the study and reviewed the manuscript. MM provided the sample and reviewed the manuscript. SN, UF and MM approved it for publication. 


\section{FUNDING}

None.

\section{DATA AVAILABILITY}

All datasets generated or analysed during this study are included in the manuscript.

\section{ETHICS STATEMENT}

The study protocol was carefully reviewed and approved by the Institutional Ethics Committee of the Teerthankar Mahaveer Medical College and Research Centre.

\section{REFERENCES}

1. Nasiri M.J., Rezaei F., Zamani S., Sarokhalil D., Fooladi A., Shojaei H. Drug resistance pattern Mycobacterium tuberculosis isolates from patients of five provinces of Iran. Asian Pac. J. Trop. Med., 2014; 7(3): 193-96.

2. Shamaei M., Marjani M., Baghaei P., Chitsaz E., Razaei E., Abrishami Z. et al. Drug abuse profile- patient delay, diagnosis delay and drug resistance pattern among addict patient with tuberculosis. Int. J. STD AIDS, 2009; 20(5): 320-23.

3. World Health Organization. Anti-tuberculosis drug resistance in the world. Report no. 4. WHO/HTM/ TB/2008.394. Geneva: World Health Organization Press: 2008.

4. Pourakbari B., Mamishi S., Mohammadzadeh M., Mahmoudi S. First line anti-tubercular drug resistance of Mycobacterium tuberculosis in Iran. A systemic review. Front Microbiol., 2016; 28(7): 1139-43.

5. Guidelines on programmatic management of drug resistant TB in India, Revised National Control Programme (RNTCP). Central Tuberculosis Division, Directorate General of health services, Ministry of Health \& Family Welfare; 2012.

6. Sharma S.K., Kaushik G., Jha B., George N., Arora S.K., Gupta D. et al. Prevalence of multidrug resistant tuberculosis among newly diagnosed cases of sputum positive pulmonary tuberculosis. Indian J. Med. Res., 2011; 133(3): 308-11.

7. Nudrat S., Farooq U., Mohan S. Utility of Line Probe Assay for identification of MDR-TB and NTM in smear positive sputum samples from a tertiary care hospital of western U.P. India. Indian J. Sci. Res., 2017; 8(1): 131-36.

8. Instruction for use Geno Type MTBDRplus Ver 2.0. HAIN Life Sciences Germany.

9. Singhal R., Myneed V.P., Arora J., Singh N., Bhalla M., Verma A. et al. Early detection of multi drug resistance and common mutations in Mycobacterium tuberculosis isolates from Delhi using GenoType MTBDRplus assay. Indian J. Med. Micro., 2015; 33(5): 46-52.

10. Rao S. Tuberculosis and patent gender: An analysis and its implication in tuberculosis control. Lung India, 2009; 26(2): 46-47.

11. World Health Organization (WHO) Fact Sheet. 2018. www.who.int

12. Gupta H., Kant S., Jain A., Natu S.M., Ahiuwalia S. Initial drug resistance pattern among pulmonary tuberculosis patients. Indian J. Tuberc., 2013; 60(3): 154-61.

13. Malhotra B., Pathak S., Vyas L., katoch V.M., Srivastava K., Chauhan D.S. et al. Drug susceptibility profile of Mycobacterium tuberculosis isolates at Jaipur. Indian J. Med. Microbiol., 2002; 20(2): 76-78.

14. Thakur C., Kumar V., gupta A.K. Pattern of drug resistant Mycobacterium tuberculosis isolates in Himachal Pradesh using Genotype MTBDR assay. Indian J. Med. Microbiol., 2015; 33(4): 547-53.

15. Ahmed S., Shukla I., Fatima N., Vaeshney S., Shameem M. Evaluation of Genotype MTBDplus line probe assay in detection of rifampicin and isoniazid resistance in comparison to solid culture drug susceptibility testing in a tertiary care centre of western U.P. Indian J. Med. Microbiol., 2017; 35(4): 68-74.

16. Tripathi R., Anupurba S. Multi drug resistant tuberculosis detection and characterization of mutation in Mycobacterium tuberculosis by Genotype MTBDR plus. Indian J. Pathol. Microbiol., 2017; 60(2); 239-42.

17. Singhal R., Prasad V., Arora J., Sinhg N., Sah G., Sarin R. Detection of multi drug resistance and characterization of mutation in Mycobacterium tuberculosis isolates from North Eastern States of India using genotype MTBDRplus assay. Indian J. Med. Res., 2014; 140(4): 501-06.

18. Talesse N., Aragaw D., Dimah B., Efa F., Abdella K., Kebede W. et al. Drug resistance conferring mutations in Mycobacterium tuberculosis from pulmonary tuberculosis patients in Southwest Ethopia. Int. J. mycobacteriol., 2016; 5(2): 185-91.

19. Hirani N., Joshi A., Menon S., wabale V., Medhekar P., Chowdhary A. Evaluation of molecular line probe assay for rapid detection of MDR TB in a tertiary care hospital setting in Mumbai, Indian J. Clin. Biotech. Microbiol, 2017; 1.1: 22-30.

20. Sharma B.K., Bhandari S. et al. Rapid detection of rifampicin and isoniazid resistant Mycobacterium tuberculosis using Genotype MTBDRplus assay in Nepa. I Int Sch Res Notices. 2014, Article I.D. 648294. doi 10.1155/2014/648294.

21. Swaminathan S., Sundaramurthi J.C., Palaniappan A.N., Narayanan S. Recent development in genomics, bioinformatics and drug discovery to combat emerging drug resistant tuberculosis. Tuberculosis, 2016; 101: 31-40. doi: 10.1016/j.tube.2016.08.002.

22. Meaza A., Kebede A., Yaregal Z., Dagne Z., Moga S., Yenew B. et al. Evaluation of Genotype MTBDR plus ver2.0 line probe assay for the detection of MDR TB in smear positive sputum samples. BMC Inf. Dis., 2017; 17: 280 . 